\title{
Glycine Receptor Knock-In Mice and Hyperekplexia-Like Phenotypes: Comparisons with the Null Mutant
}

\author{
Geoffrey S. Findlay, ${ }^{1}$ Rachel Phelan, ${ }^{1}$ Michael T. Roberts, ${ }^{1}$ Gregg E. Homanics, ${ }^{2}$ Susan E. Bergeson, ${ }^{1}$ \\ Gregory F. Lopreato, ${ }^{1}$ S. John Mihic, ${ }^{1}$ Yuri A. Blednov, ${ }^{1}$ and R. Adron Harris ${ }^{1}$ \\ ${ }^{1}$ Waggoner Center for Alcohol and Addiction Research, Section of Neurobiology, University of Texas at Austin, Austin, Texas 78712, and ${ }^{2}$ Departments of \\ Anesthesiology and Pharmacology, University of Pittsburgh School of Medicine, Pittsburgh, Pennsylvania 15261
}

Strychnine-sensitive glycine receptors (GlyRs) inhibit neurotransmission in the spinal cord and brainstem. To better define the function of this receptor in vivo, we constructed a point mutation that impairs receptor function in the $\alpha_{1}$-subunit and compared these knock-in mice to oscillator $\left(s p d^{o t}\right)$ mice lacking functional GlyR $\alpha_{1}$-subunits. Mutation of the serine residue at amino acid 267 to glutamine $\left(\alpha_{1} \mathrm{~S} 267 \mathrm{Q}\right)$ results in a GlyR with normal glycine potency but decreased maximal currents, as shown by electrophysiological recordings using Xenopus oocytes. In addition, single-channel recordings using human embryonic kidney 293 cells indicated profoundly altered properties of the mutated GlyR. We produced knock-in mice bearing the GlyR $\alpha_{1}$ S267Q mutation to assess the in vivo consequences of selectively decreasing GlyR efficacy. Chloride uptake into brain synaptoneurosomes from knock-in mice revealed decreased responses to maximally effective glycine concentrations, although wild-type levels of GlyR expression were observed using ${ }^{3} \mathrm{H}$-strychnine binding and immunoblotting. A profound increase in the acoustic startle response was observed in knock-in mice as well as a "limb clenching" phenotype. In contrast, no changes in coordination or pain perception were observed using the rotarod or hot-plate tests, and there was no change in $\mathrm{GABA}_{\mathrm{A}}$-receptor-mediated chloride uptake. Homozygous S267Q knock-in mice, like homozygous spd $d^{\text {ot }}$ mice, exhibited seizures and died within 3 weeks of birth. In heterozygous $s p d^{o t}$ mice, both decreased ${ }^{3} \mathrm{H}$-strychnine binding and chloride flux were observed; however, neither enhanced acoustic startle responses nor limb clenching were seen. These data demonstrate that a dominantnegative point mutation in GlyR disrupting normal function can produce a more dramatic phenotype than the corresponding recessive null mutation, and provides a new animal model to evaluate GlyR function in vivo.

Key words: GlyR; knock-in; oscillator; spd-ot; mice; channel gating; glycine; hyperekplexia; strychnine; chloride flux; Xenopus oocytes; acoustic startle response

\section{Introduction}

Glycine receptors (GlyRs) are the primary inhibitory neurotransmitter receptors in the brainstem and spinal cord. GlyRs are pentameric ligand-gated ion channels that conduct chloride in response to the neurotransmitter glycine and are inhibited by the competitive antagonist strychnine. Four GlyR $\alpha$-subunits and one $\beta$-subunit have been identified. GlyRs are typically composed of three $\alpha$-subunits and two $\beta$-subunits. Although the $\alpha_{2}$ subunit is found throughout the prenatal brain and is important for synaptogenesis, the $\alpha_{1}$-subunit predominates in the adult spinal cord and brainstem, whereas the $\beta$-subunit is widely distributed in the brain (Laube et al., 2002). The $\beta$-subunit localizes GlyR at the synapse by binding gephyrin, which in turn binds to microtubules (Kirsch and Betz, 1995; Meyer et al., 1995). Although the $\alpha_{1}$-subunit can form functional GlyRs in vitro that exhibit properties similar to those of native GlyRs, the $\beta$-subunit

\footnotetext{
Received Feb. 13, 2003; revised July 8, 2003; accepted July 17, 2003.

This work was supported by National Institute on Alcohol Abuse and Alcoholism Grants AA11525 and AA13520. We thank Marilee Wick and Carolyn Ferguson for molecular expertise and Virginia Bleck for assistance in genotyping mice.

Correspondence should be addressed to Dr. Adron Harris, Waggoner Center for Alcohol and Addiction Research (A4800), The University of Texas at Austin, Austin, TX 78712. E-mail: harris@mail.utexas.edu.

Copyright $\odot 2003$ Society for Neuroscience $\quad 0270-6474 / 03 / 238051-09 \$ 15.00 / 0$
}

is important for GlyR function in vivo (Becker et al., 1992) and coassembles with the $\alpha_{1}$-subunit (Kuhse et al., 1995). Specific point mutations in GlyR $\alpha_{1}$ can cause dominant hyperekplexia ("startle disease"), in which an exaggerated response to acoustic stimuli can result in uncontrolled falling (Shiang et al., 1993).

Oscillator $\left(s p d^{o t}\right)$ mice possess a $7 \mathrm{bp}$ deletion in the GlyR $\alpha_{1}$-subunit gene that results in a complete loss of $\alpha_{1}$-subunits in mice homozygous for the $s p d^{o t}$ mutation and is lethal in mice homozygous for this deletion (Buckwalter et al., 1994). In contrast, loss of $50 \%$ of $\alpha_{1}$-subunits in heterozygous spd $d^{\text {ot }}$ mice leads to a relatively mild behavioral phenotype (Kling et al., 1997). We hypothesized that mice harboring a mutation leading to GlyR hypofunction by disrupting the function at each individual GlyR (dominant-negative effect), rather than decreasing the number of GlyR (haplotype insufficiency), would result in a different mode of receptor function reduction. This in turn might preclude the compensation or subunit substitution that appears to occur in mice with reduced levels of GlyR protein (Kling et al., 1997). We hypothesized that this might result in a more dramatic phenotype in vivo. To test this hypothesis, we generated knock-in mice possessing the GlyR $\alpha_{1}$ serine to glutamine (S267Q) mutation that decreases glycine efficacy and compared them with the corresponding GlyR $\alpha_{1}$ null mutant mice. The knock-in ap- 
proach represents a powerful and proven technique for evaluating the significance of receptor function in vivo (Low et al., 2000; McKernan et al., 2000; Crestani et al., 2001).

\section{Materials and Methods}

Oocyte electrophysiology. Two-electrode voltage-clamp electrophysiological recordings were performed on Xenopus laevis oocytes as described previously (Mihic et al., 1997; Findlay et al., 2001). The effect of the S267Q mutation of the $\alpha_{1}$-subunit was compared in homomeric $\alpha_{1}$ and heteromeric $\alpha_{1} \beta$ GlyR. Oocytes were injected with either wild-type or mutated human GlyR $\alpha_{1}$ cDNAs individually or in combination with the wild-type GlyR $\beta$-subunit at a ratio of $30 \beta: 1 \alpha$ to reach a final concentration of $1.5 \mathrm{ng} / 30 \mathrm{nl}$. Wild-type $\alpha$ and $\beta$ cDNAs were subcloned into the $\mathrm{PBKCMV}$ vector that had been modified previously by removal of the lac promoter and the lacZ ATG (Mihic et al., 1997). The S267Q GlyR $\alpha_{1}$ cDNA was subcloned into the pCIS vector. Electrophysiological measurements were made $4-14 \mathrm{~d}$ after the cDNA injection in a counterbalanced design, such that each group contained an equal number of oocytes from each frog, and oocytes in each group were tested at equal times after cDNA injection. All oocytes received an initial $15 \mathrm{sec}$ application of $200 \mu \mathrm{M}$ glycine to test for GlyR expression. If oocytes did express GlyR, experiments were started after an $8 \mathrm{~min}$ wash-out period. All experimental glycine applications were $30 \mathrm{sec}$ in duration, with wash-out periods (5-18 min) long enough to ensure complete resensitization between drug applications. Oocytes were constantly perfused with modified Barth's saline (Beckstead et al., 2000) buffer (with or without glycine) at a rate of $2 \mathrm{ml} / \mathrm{min}$. Peak currents were measured and used in data analysis.

Single-channel recordings. Single-channel recordings were made from outside-out patches pulled from human embryonic kidney 293 (HEK 293) cells transiently transfected with cDNAs encoding either wild-type or S267Q $\alpha_{1}$ glycine receptor subunits. Briefly, HEK 293 cells obtained from ATCC (Manassas, VA) were cultured in a $5 \% \mathrm{CO}_{2}$ atmosphere at $37^{\circ} \mathrm{C}$ in DMEM + L-glutamine + sodium pyruvate $+10 \%$ fetal bovine serum (Invitrogen, Carlsbad, CA). Cells were split every 2-3 d using $0.25 \%$ trypsin and $1 \mathrm{~mm}$ EDTA in HBSS (Invitrogen) and were used through passage 20 . The day before transfection, cells were split onto 15 mm Thermanox coverslips (Nunc, Rochester, NY). Transfections were carried out using a GlyR-optimized calcium phosphate transfection protocol (Groot-Kormelink et al., 2002). Transfected cells were used for experiments 1-2 d later.

Outside-out patch recordings were made according to standard methods (Hamill et al., 1981). Patch pipettes were pulled from thick-walled borosilicate glass (Sutter Instruments, Novato, CA), coated with Sylgard 184 (Dow Corning, Midlands, MI), and fire polished to tip resistances of $8-15 \mathrm{M} \Omega$. The pipette solution was composed of the following (in $\mathrm{mM}$ ): $145 \mathrm{CsCl}, 2 \mathrm{CaCl}_{2}, 2 \mathrm{MgCl}_{2}, 10$ HEPES, and 10 EGTA, pH 7.3, with $\mathrm{CsOH}$. The bath was perfused with, and glycine solutions were prepared in, an external solution containing the following (in $\mathrm{mm}$ ): $140 \mathrm{NaCl}, 5$ $\mathrm{KCl}, 2 \mathrm{CaCl}_{2}, 1 \mathrm{MgCl}_{2}, 10$ HEPES, and 10 glucose, $\mathrm{pH}$ 7.4, with $\mathrm{NaOH}$. Glycine applications were made using the SF-77B Perfusion Fast-Step apparatus (Warner Instruments, Hamden, CT). Data were acquired using an Axopatch 200B amplifier (Axon Instruments, Union City, CA) interfaced with a Pentium class computer running pClamp 8.0 software (Axon Instruments). Single-channel data were low-pass-filtered at 3-5 $\mathrm{kHz}(-3 \mathrm{~dB}$, four pole Bessel), digitized at $30 \mathrm{kHz}$, stored on a hard drive, and analyzed using Clampfit (Axon Instruments).

Mouse production. A mouse strain 129/SvJ BAC genomic DNA library (Genome Systems, St. Louis, MO) was screened with an $\sim 700 \mathrm{bp} \mathrm{ApaI}$ fragment of the human glycine $\alpha_{1}$-receptor cDNA. This fragment contained the putative transmembrane region $2(\mathrm{TM} 2)$ region. A $\sim 10 \mathrm{~kb}$ HindIII-Pst I subclone was used to create the targeting construct illustrated in Figure 3. The Quickchange Site Directed Mutagenesis kit (Stratagene, La Jolla, CA) was used to change three nucleotides in exon 7 so that the codon for serine (AGC) at position 267 now encoded glutamine (CAG). In addition to changing the codon, this mutation also destroyed an SstI restriction site. A neomycin resistance cassette that was flanked by FLP recombinase target sites (Meyers et al., 1998) was inserted into intron 7 in a NheI site and a HSV-TK (herpes simplex virus-tyrosine kinase) cassette was inserted at the $5^{\prime}$ end of the targeting construct. The vector was linearized with NotI and introduced into strain 129/SvJ "Go Germline" mouse embryonic stem (ES) cells (Genome Systems) as described previously (Homanics et al., 1997). ES cells that survived G418 selection were screened for targeting by Southern blot analysis of HindIII-digested DNA and hybridization with a $3^{\prime}$ probe that is external to the targeting construct. This probe was an $\sim 350 \mathrm{bp}$ PstI-HindIII genomic subclone that spanned exon 8 . Correctly targeted clones were also analyzed with additional enzymes, including SstI, and probes (data not shown).

Correctly targeted ES cell clones were microinjected into C57BL/6J blastocysts to produce chimeric animals. Highly chimeric mice were mated to $\mathrm{C} 57 \mathrm{BL} / 6 \mathrm{~J}$ mice to produce the first filial $\left(\mathrm{F}_{1}\right)$ generation. Mice heterozygous for the neo-containing knock-in $(\mathrm{KI})$ allele $\left(\mathrm{S} / \mathrm{Q}_{\text {neo }}\right)$ were mated to enhanced FLP (FLPe) general deleter mice (Rodriguez et al., 2000) (C57BL/6 background) to remove the neo marker cassette. The FLPe transgene was detected on Southern blot analysis with an $\sim 500 \mathrm{bp}$ EcoRI/EcoRV fragment of the FLPe coding sequence. For the experiments described here, all knock-in mice were of a mixed genetic background of $(\mathrm{C} 57 \mathrm{BL} / 6 \mathrm{~J} \times 129 / \mathrm{SvJ})$ of the $\mathrm{F}_{3-4}$ generations. Littermate mice bearing wild-type $\alpha_{1}$ GlyR subunits served as controls in behavioral and biochemical experiments.

PCR genotyping for GlyKI mice was performed by using a forward primer (sequence: CCTGCTCATCGTCATCCT) and a reverse primer (sequence: TGCAGCTCTCTCCTCCTC) with an annealing temperature of $55^{\circ} \mathrm{C}$ to amplify a fragment of the genomic GlyR $\alpha_{1}$-subunit. These primers flank the GlyR $\alpha_{1}$ S267Q mutation. The fragment was subsequently digested with $\mathrm{SacI}$ and run on a $4 \%$ MetaPhor/TBE gel. The wild-type gene produced two bands: 185 and $110 \mathrm{bp}$; homozygous knock-in mice were observed because of a single band: 295 bp; heterozygous mice were identified by three bands: 295,185 , and $110 \mathrm{bp}$. The point mutation S267Q in heterozygous or homozygous mice was observed because of the elimination of a SacI cut site by the mutation. This genotyping protocol was confirmed using Southern blotting.

Heterozygous $+/ s p d^{o t}$ mice carrying the oscillator mutation on a C57BL/6J background were purchased from Jackson Laboratories (Bar Harbor, ME) to establish a breeding colony in our facility. PCR genotyping for $s p d^{o t}$ mice was performed as described previously (Kling et al., 1997). In all cases, wild-type littermates were used as controls for comparison with mutant mice.

Cloning of GlyR $\alpha_{1}$ cDNA. RNA was extracted from spinal cord and brainstem tissue using a modified phenol-chloroform extraction protocol. Brainstem and spinal cord tissues were isolated and immediately frozen in liquid nitrogen before being stored at $-70^{\circ} \mathrm{C}$ overnight. Frozen tissue samples were placed into $2 \mathrm{ml}$ of Trizol reagent (Invitrogen, Carlsbad, CA) and immediately homogenized using a Powergen 700 (Fisher Scientific, Pittsburgh, PA) for $2 \mathrm{~min}$. The tissue was incubated at room temperature for $5 \mathrm{~min}$, followed by centrifugation at $12,000 \times \mathrm{g}$ for 10 $\min$ at $4^{\circ} \mathrm{C}$. Chloroform $(0.2 \mathrm{ml} / 1 \mathrm{ml}$ reagent $)$ was added to the supernatant, and the solution was shaken vigorously for $30 \mathrm{sec}$. After $2 \mathrm{~min}$ of incubation at room temperature, the solution was centrifuged at $12,000 \times g$ for $15 \mathrm{~min}$ at $4^{\circ} \mathrm{C}$. The top aqueous phase was removed and isopropanol ( $0.5 \mathrm{ml} / 1 \mathrm{ml}$ reagent) was added and mixed. After $10 \mathrm{~min}$ of incubation at room temperature, the solution was centrifuged at $12,000 \times g$ for $10 \mathrm{~min}$ at $4^{\circ} \mathrm{C}$. The RNA pellets were recovered by aspiration of the supernatant and then washed with $70 \%$ ethanol $(1 \mathrm{ml} / \mathrm{ml}$ reagent) and then centrifuged at $7500 \times g$ for $10 \mathrm{~min}$ at $4^{\circ} \mathrm{C}$. The pellet was air-dried and resuspended in diethylpyrocarbonate (DEPC)-double distilled $\mathrm{H}_{2} \mathrm{O}$ and stored at $-70^{\circ} \mathrm{C}$. RNA quality was analyzed using a RNA Nano Chip with an Aligent 2100 Bioanalyzer (Aligent Technologies, Waldbrom, Germany). Reverse transcription of the RNA was performed using Superscript II (Invitrogen, Carlsbad, CA). GlyR $\alpha_{1}$ cDNA was amplified with PCR using a primer upstream (sequence: CGTGGACTTTACAGCACT) and downstream (sequence: CCTCCCACCACCCTCTCC) from the coding region of the GlyR $\alpha_{1}$ cDNA, with an annealing temperature of $54^{\circ} \mathrm{C}$. The GlyR $\alpha_{1}$ cDNA was then cloned using the TA cloning kit (Promega, Madison, WI) and sequenced. Primers for both complementary strands were used.

Immunoblot analysis. Immunoblot analysis of combined spinal cord and brainstem tissues was performed as described previously (Findlay et al., 2002), using a polyclonal antibody to the $\mathrm{N}$-terminal of the $\sim 48 \mathrm{kDa}$ 
GlyR $\alpha$-subunit (rabbit anti-glycine receptor antibody; Chemicon International, Temecula, CA; Wick et al., 1999). After testing a range (1.25-30 $\mu \mathrm{g}$ of protein) of tissue amounts, a moderate (10 $\mu \mathrm{g}$ of protein) amount of tissue was used for each sample in the immunoblots.

Glycine-stimulated chloride $\left({ }^{36} \mathrm{Cl}^{-}\right)$uptake of synaptoneurosomes. Isolated brainstem and spinal cord membrane vesicles (synaptoneurosomes) were prepared as described previously (Blednov et al., 1996), with modifications. The tissue was homogenized in $4.5 \mathrm{ml}$ of assay buffer containing the following (in mM): $145 \mathrm{NaCl}, 5 \mathrm{KCl}, 1 \mathrm{MgCl}_{2}, 10$ glucose, $1 \mathrm{CaCl}_{2}, 10$ HEPES, $\mathrm{pH} 7.5$, using Tris-base) using a hand homogenizer (Thomas Scientific, Swedesboro, NJ), and the tissue was then centrifuged at $900 \times g$ for $15 \mathrm{~min}$. Combined brainstem and spinal cord samples were resuspended in $10 \mathrm{ml}$ of assay buffer, and the suspensions were then filtered through one layer of $100 \mu \mathrm{m}$ nylon microfilament cloth (PGC Scientific, Frederick, MD) to remove myelin. Samples were then centrifuged again at $900 \times g$ for $15 \mathrm{~min}$. The pellet was suspended in ice-cold assay buffer and tissue aliquots $(0.8-1.2 \mu \mathrm{g}$ of protein) were incubated at $34^{\circ} \mathrm{C}$ for $15 \mathrm{~min}$ in the presence or absence of $500 \mu \mathrm{M}$ strychnine. Uptake was initiated by adding $200 \mu \mathrm{l}$ of ${ }^{36} \mathrm{Cl}^{-}$solution $(2 \mu \mathrm{Ci} / \mathrm{ml}$ of assay buffer) containing glycine (50-500 $\mu \mathrm{m}$ final concentration). The influx reaction was terminated $9 \mathrm{sec}$ later by the addition of $4 \mathrm{ml}$ of ice-cold quench buffer (assay buffer containing $0.1 \mu \mathrm{M}$ strychnine) and rapid filtration through a GB100R filter (Advantec MFS, Dublin, CA). The filter was then washed once with $8 \mathrm{ml}$ of quench buffer. Filters were incubated in $4 \mathrm{ml}$ of Biosafe II scintillation liquid (Research Products International, Mount Prospect, IL) before analysis in a Beckman LS 6500 scintillation counter (Beckman Coulter, Fullerton, CA). The amount of ${ }^{36} \mathrm{Cl}^{-}$that was bound to the filter in the absence of membrane (no-tissue blank) was subtracted from all values. Glycine-dependent chloride uptake was defined as the amount of chloride taken up while agonist was present in the medium (total intake) minus the amount taken up in the absence of agonist (glycine-independent or basal uptake). Strychninesensitivity was determined by comparing the basal chloride uptake with the glycine-stimulated chloride uptake in the presence of strychnine.

$\left[{ }^{3} \mathrm{H}\right]$ strychnine binding. $\left[{ }^{3} \mathrm{H}\right]$ strychnine binding was performed as reported previously (Findlay et al., 2002). Specific binding was calculated by subtracting nonspecific binding (in the presence of glycine) from total binding. $K_{\mathrm{d}}$ and $B_{\max }$ values were calculated for each individual saturation curve using the Prism 2.0 program (GraphPad Software, San Diego, CA).

Behavioral experiments and phenotype analysis. Acoustic startle responses were measured using SR-LAB test stations and software (San Diego Instruments, San Diego, CA). Test stations were both standardized and calibrated, and startle responses are expressed in milliNewtons. Startle responses were recorded as described previously (Bullock et al., 1997). After a 3 min acclimation period, trials of single $40 \mathrm{msec}$ bursts of white noise ranging from 95 to $125 \mathrm{~dB}$ were presented in a pseudorandom order with a $10 \mathrm{sec}$ intertrial interval. The background noise was $70 \mathrm{~dB}$. Eight no-stimulus recordings were recorded at pseudorandom intervals to measure spontaneous activity. Each stimulus (with the exception of the no-stimulus trial) was presented 15 times. The entire session comprised 113 trials and took $22 \mathrm{~min}$. The highest and lowest responses to each stimulus intensity and the no-stimulus recordings were excluded. The average response to a stimulus trial at a given sound (decibel) intensity was defined as the average startle response minus the average of the background no-stimulus trials.

Locomotor activity was performed as described previously (Findlay et al., 2002). Total beam breaks were measured in $30 \mathrm{~min}$ increments over a $24 \mathrm{hr}$ period for each mouse tested.

Hot-plate latency was determined by placing a mouse on a Hotplate Analgesia Meter (Columbus Instruments, Columbus, $\mathrm{OH}$ ) set at a constant temperature of $52.5^{\circ} \mathrm{C}$. Latency was defined as the time that elapsed between the mouse being placed on the hotplate and when it engaged in stereotypical behaviors such as paw licking, rearing on hindlegs, or leg lifting.

Rotarod coordination was determined by first training mice on a rotarod (Economex; Columbus Instruments, Columbus, $\mathrm{OH}$ ) at $2.5 \mathrm{rpm}$ until they were able to walk on it for $1 \mathrm{~min}$. Successively increasing speeds were then tested: $5,7.5,10,12.5$, and $15 \mathrm{rpm}$. Success was defined as the mouse remaining on the moving rotarod for $1 \mathrm{~min}$. Failure was defined
A

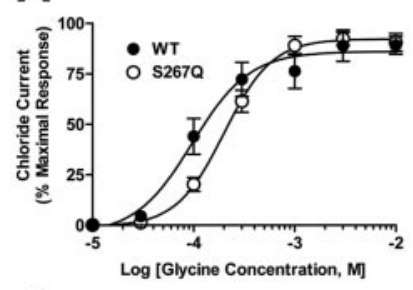

B

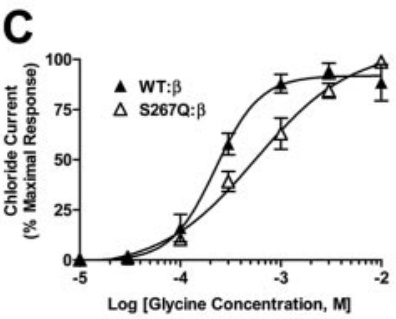

D

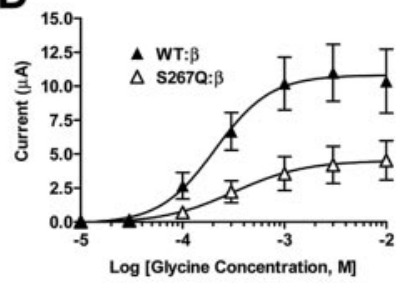

Figure 1. Glycine concentration-response relationships of wild-type (WT) or mutant $\$ 2670$ $\alpha_{1}$ GlyR expressed in Xenopus laevis oocytes. A, Electrophysiological responses of WT (filled circles) or $\$ 267 Q$ (open circles) GlyR to varying concentrations of glycine $(0.01-10 \mathrm{~mm}$ ) were measured ( $n=7-8$ per point). The responses are expressed as a percentage of the maximal response for each oocyte. WT and S267Q concentration-response relationships were statistically indistinguishable using a two-way ANOVA followed by Tukey's multiple comparisons. Glycine $\mathrm{EC}_{50}$ values were $0.2 \pm 0.08$ and $0.2 \pm 0.04 \mu \mathrm{m}$, and Hill coefficients were $2.3 \pm 0.5$ and $1.9 \pm 0.3$ for WT and S267Q GlyR, respectively. $B$, The data from $A$ expressed as absolute currents. A two-way ANOVA followed by Tukey's multiple comparisons reveal that the concentration-response curves for WT and $S 2670$ are significantly different $(p<0.01, n=7-8$ per point). $E_{\max }$ values were $24 \pm 5$ and $10 \pm 2 \mu \mathrm{A}$ in WT and S267Q GlyR ( $p<0.05$ using a two-tailed $t$ test, $n=7-8$ per point). $\mathrm{EC}_{50}$ or Hill values were the same as calculated in $A$ using normalized data. C, Electrophysiological responses to glycine $(0.01-10 \mathrm{~mm})$ of either heteromeric WT (filled triangles) or $\$ 2670$ (open triangles) $\alpha_{1}$-subunit coexpressed with the $\beta$-subunit. WT and mutant concentration-response relationships were statistically different as measured by a two-way ANOVA followed by Tukey's multiple comparisons ( $p<0.05, n=$ 5-8 per point). Glycine $\mathrm{EC}_{50}$ values were $0.2 \pm 0.04$ and $1.0 \pm 0.3 \mathrm{~mm}(p>0.05)$, and Hill coefficients were $1.8 \pm 0.4$ and $1.1 \pm 0.2(p>0.05)$ for WT and $\alpha_{1}($ S2670) $\beta$ GlyR. D, The data from $C$ are presented as the absolute currents. A two-way ANOVA followed by Tukey's multiple comparisons revealed that the concentration-response curves were significantly different $\left(p<0.01, n=5-8\right.$ per point). $E_{\max }$ values were $11 \pm 2$ and $4.7 \pm 1 \mu \mathrm{A}$ in WT and $\alpha_{1}(\mathrm{~S} 2670) \beta$ GlyR ( $p<0.05$ using two-tailed $t$ test, $n=5-8$ per point). $\mathrm{EC}_{50}$ or Hill values were the same as calculated in C using normalized data. In all panels, $\mathrm{EC}_{50}, E_{\max }$, and Hill values were calculated from concentration-response curves obtained from individual oocytes.

as the mouse falling from the rotarod four times. If the mouse failed at a given speed, higher speeds were not tested. The highest speed of success for each mouse was recorded and analyzed statistically. Adult mice, age 2-4 months, were tested in all behavioral experiments.

Statistical analysis. Student $t$ tests, one-way and two-way ANOVAs, and curve-fitting were performed using the Prism 3.0 program (GraphPad Software) or Origin 7 (Microcal Software, Northampton, MA). All graphs are represented as means \pm SEM with levels of significance indicated as ${ }^{\star} p<0.05,{ }^{* *} p<0.01$, and ${ }^{* *} p<0.001$.

\section{Results}

The effects of the GlyR $\alpha_{1}$ S267Q mutation were investigated in Xenopus oocytes by expressing wild-type or mutant S267Q GlyR $\alpha_{1}$ cDNA and measuring currents produced by glycine. If results were expressed as the percent of the maximal current observed in each oocyte, no differences were observed between homomeric GlyR $\alpha_{1}$ S267Q and the wild-type receptors, indicating that the mutation did not alter the potency of glycine (Fig. $1 A$ ). However, when these same data were expressed as absolute currents, a decreased maximal response was seen in the S267Q mutant (Fig. $1 B)$. The S267Q mutation also produced a large decrease in the maximal response to glycine in $\alpha_{1} \beta$ heteromeric receptors (Fig. $1 D)$. Results obtained from multiple batches of oocytes tested 


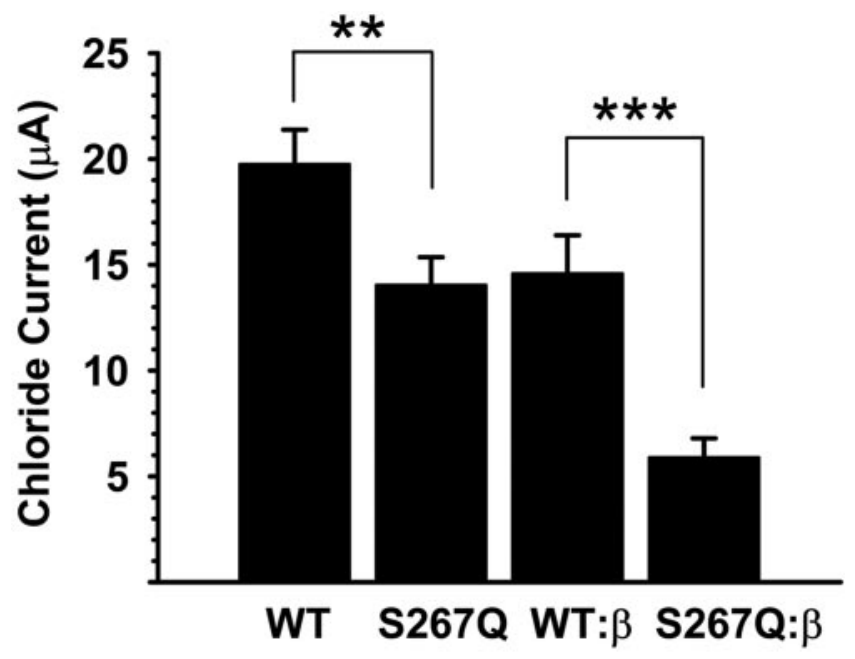

Figure 2. Oocytes injected with CDNA encoding either the WT or $\$ 2670$ mutant $\alpha_{1}$ GlyRs individually or coexpressed with the $\beta$-subunit. All oocytes were tested for expression with 200 $\mu \mathrm{m}$ glycine ( $15 \mathrm{sec}$ ) and, after an $8 \mathrm{~min}$ wash-out, $10 \mathrm{~mm}$ glycine $(30 \mathrm{sec}$ ) to obtain the maximal currents. Oocytes that did not express any glycine response were excluded from the analysis. $t$ tests revealed significant differences (WT vs $\$ 2670$ homomeric receptors, $p=0.008, \mathrm{df}=54$; WT: $\beta$ vs S2670: $\beta$ heteromeric receptors, $p=0.0001, \mathrm{df}=58 ; n=25-33$ per group).

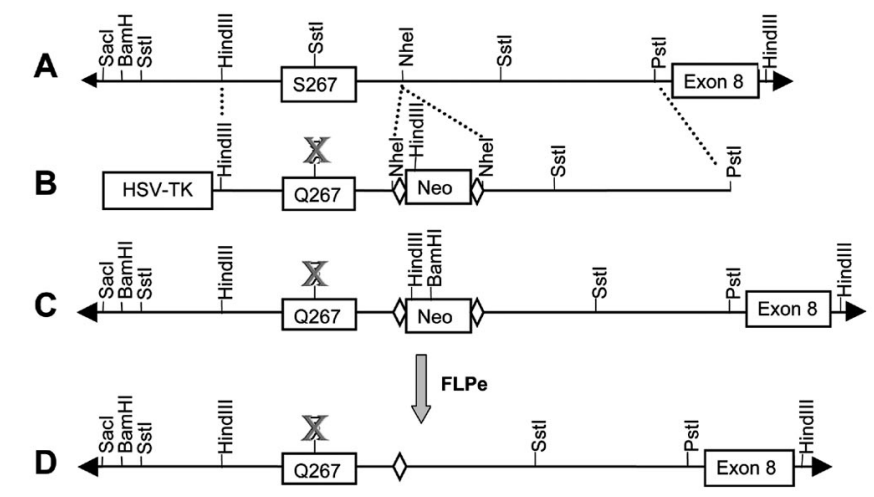

Figure 3. $\mathrm{S} 2670 \alpha_{1}$ GlyR knock-in strategy and construct. $A$, Wild-type endogenous mouse GlyR $\alpha_{1}$ locus. $B$, DNA targeting construct used for gene targeting in ES cells to create the knock-in allele. C, Gene targeted knock-in allele with the Q267 mutation and the neomycin cassette (Neo) flanked by two FLP recombinase target sites $(\nabla)$. An Sstl site was eliminated by the $\$ 267$ Q mutation. D, Knock-in locus after FLPe-mediated deletion of the neomycin marker cassette by site-specific recombination.

showed a consistent decrease in the maximal glycine-stimulated currents as a result of the S267Q mutation when the $\alpha_{1}$-subunit was expressed homomerically ( $\sim 30 \%$ reduction $)$, or heteromerically with the $\beta$-subunit ( $\sim 60 \%$ reduction) (Fig. 2 ).

To evaluate the in vivo consequences of the GlyR $\alpha_{1}$ S267Q mutation, knock-in mice bearing this mutation were generated (Fig. 3). To ensure that the knock-in mice carried only the desired mutation, knock-in and wild-type cDNAs for the GlyR $\alpha_{1}$ subunit gene were cloned and sequenced. Two splice variants exist for the GlyR $\alpha_{1}$-subunit (Malosio et al., 1991) and both were observed for wild-type and mutant cDNA. Wild-type cDNA was identical to the GlyR $\alpha_{1}$ sequence that we characterized previously (GenBank accession number AY129229). The knock-in cDNA was identical to the wild-type cDNA except for the intended AGC $\rightarrow$ CAG mutation that produced the S267Q mutation.

Mice homozygous for the S267Q mutation exhibited seizures and died by 3 weeks after birth. As observed previously (Kling et

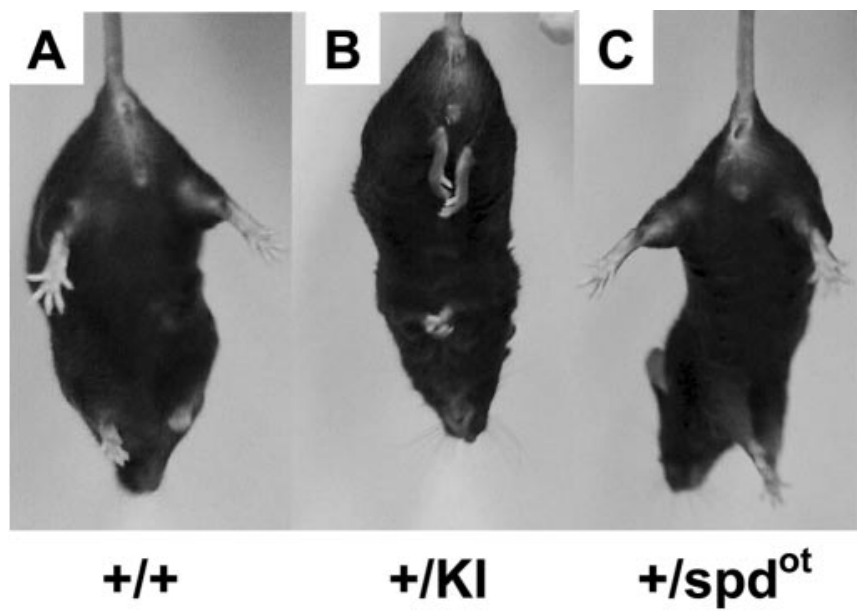

Figure 4. Hindfeet clenching or limb clenching phenotype in adult knock-in mice. Wild-type $(A)$, heterozygous knock-in $(B)$, and heterozygous $s p d^{o t}(C)$ mice were evaluated. When lifted by the tail, heterozygous knock-in mice displayed an obvious hindfeet clenching or limb clenching phenotype. Neither wild-type nor heterozygous spd $d^{\text {ot }}$ mice displayed this phenotype.

al., 1997; Findlay et al., 2002), homozygous oscillator (spd $\left.d^{o t} / s p d^{o t}\right)$ mice also die within 3 weeks because of a mutation in the GlyR $\alpha_{1}$ subunit gene that results in a loss of functional $\alpha_{1}$ polypeptide. Therefore, heterozygous $s p d^{o t}$ mice were simultaneously tested with heterozygous S267Q $\alpha_{1}$ knock-in mice to allow direct comparisons to be made. Hindfeet clenching or limb clenching was consistently observed in heterozygous S267Q $\alpha_{1}$ knock-in mice when they were lifted by their tails (Fig. 4). Hindfeet clenching is associated with dominant hyperekplexia (Becker et al., 2002), but this phenotype was not observed in wild-type or heterozygous $s p d^{o t}$ mice. No spontaneous convulsions were observed in heterozygous S267Q $\alpha_{1}$ knock-in mice, and these mice were easily able to right themselves quickly when placed on their backs.

A dramatic increase in the acoustic startle responses was observed in S267Q $\alpha_{1}$ heterozygous knock-in mice (Fig. 5A). In contrast, no differences in the acoustic startle response were observed as a result of heterozygosity for the $s p d^{o t}$ mutation (Fig. $5 B$ ). Wild-type mice for both groups displayed similar acoustic startle responses. The large increase in the acoustic startle response observed in S267Q knock-in mice did not extend to a more general disruption of coordination as measured using the rotarod test. All mice were successfully trained at $2.5 \mathrm{rpm}$ on the rotarod. The highest speed of success was $11.0 \pm 1 \mathrm{rpm}(n=18)$ and $12.4 \pm 1 \mathrm{rpm}(n=17)$ for wild-type and knock-in mice, respectively. In addition, no differences were observed in spontaneous locomotor activity as a result of the knock-in mutation (data not shown). To measure pain perception, the hot-plate test was used. No differences between knock-in and wild-type mice were observed using this test; the hot-plate latency was $9.1 \pm 0.7$ $\sec (n=11)$ and $9.9 \pm 0.7 \sec (n=17)$ in wild-type and knock-in mice, respectively.

The S267Q knock-in mutation produced no differences in GlyR expression as assessed by immunoblotting and ${ }^{3} \mathrm{H}$ strychnine binding (Fig. 6). In contrast, the $s p d^{o t}$ mutation did produce a decrease in ${ }^{3} \mathrm{H}$-strychnine binding (Fig. $6 \mathrm{~B}$ ), confirming earlier work (Kling et al., 1997). Unlike transgenic mice with mutant GlyR (Becker et al., 2002; Findlay et al., 2002), no ectopic expression of GlyR was observed in the cortex of GlyR $\alpha_{1}$ S267Q knock-in mice using immunoblotting (Fig. 6A).

To evaluate GlyR function in knock-in and $s p d^{o t}$ mice, glycine-stimulated chloride $\left({ }^{36} \mathrm{Cl}^{-}\right)$uptake was determined for 

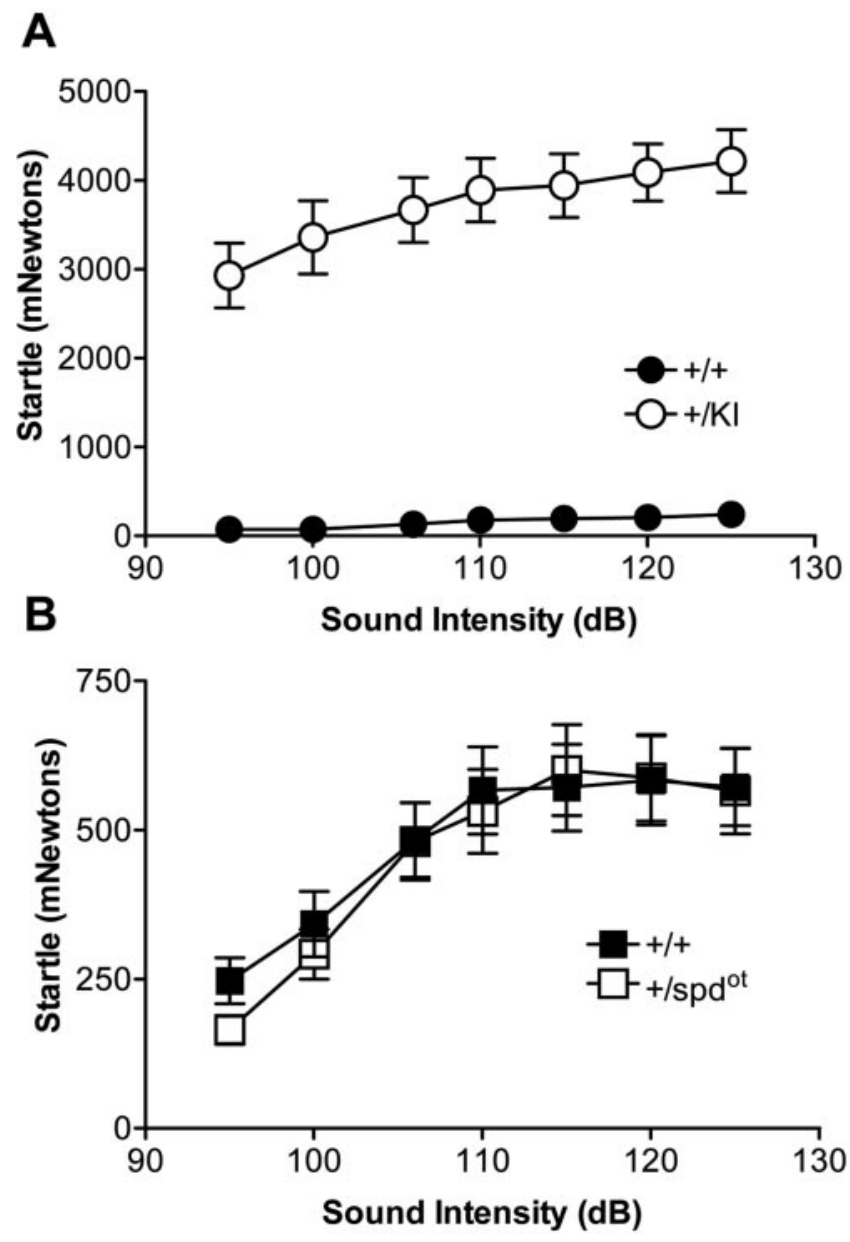

Figure 5. Acoustic startle responses. $A$, A profound increase in startle responses was observed for heterozygous knock-in mice $(+/ K \mathrm{~K})$ compared with corresponding wild-type $(+/+)$ mice $(n=17-24$ per group). $B$, No differences in acoustic startle responses were observed between heterozygous spd ${ }^{\text {dt }}\left(+/\right.$ spd $\left.^{\text {ot }}\right)$ and corresponding wild-type $(+/+)$ mice ( $n=14-15$ per group). Both groups of wild-type mice displayed similar acoustic startle responses. Note that there is a large difference in the $y$-axis between $A$ and $B$.

brainstem and spinal cord synaptoneurosomes. Glycinestimulated ${ }^{36} \mathrm{Cl}^{-}$uptake was inhibited by strychnine (data not shown). Decreased maximal responses to glycine were observed as a result of the S267Q knock-in or $s p d^{o t}$ mutations (Fig. 7A,B). A measure of ion flux per receptor (chloride uptake/ $B_{\max }$ ) was decreased for the knock-in, but not the $s p d^{o t}$ mice (Table 1). These data suggest that the S267Q mutation disrupts channel function, unlike in wild-type and $s p d^{o t}$ mice. In contrast to the changes in glycine receptor function, maximal responses to muscimol, a GABA agonist, were not altered by the knock-in mutation (Fig. 7C).

To examine the possibility that the knock-in mutation disrupts GlyR gating, single-channel recordings were made using outside-out patches pulled from HEK 293 cells transiently expressing GlyR. Consistent differences were observed between wild-type and S267Q $\alpha_{1}$ receptors. Wild-type $\alpha_{1}$ GlyR displayed bursts of channel openings to stable conductance levels, similar to those shown previously (Beato et al., 2002). However, recordings made from outside-out patches of S267Q $\alpha_{1}$ GlyR displayed brief openings that rarely attained a stable amplitude and had no resolvable bursts of openings (Fig. 8). Nonetheless, these data qualitatively support the idea that the GlyR $\alpha_{1}$ S267Q mutation severely disrupts channel function.

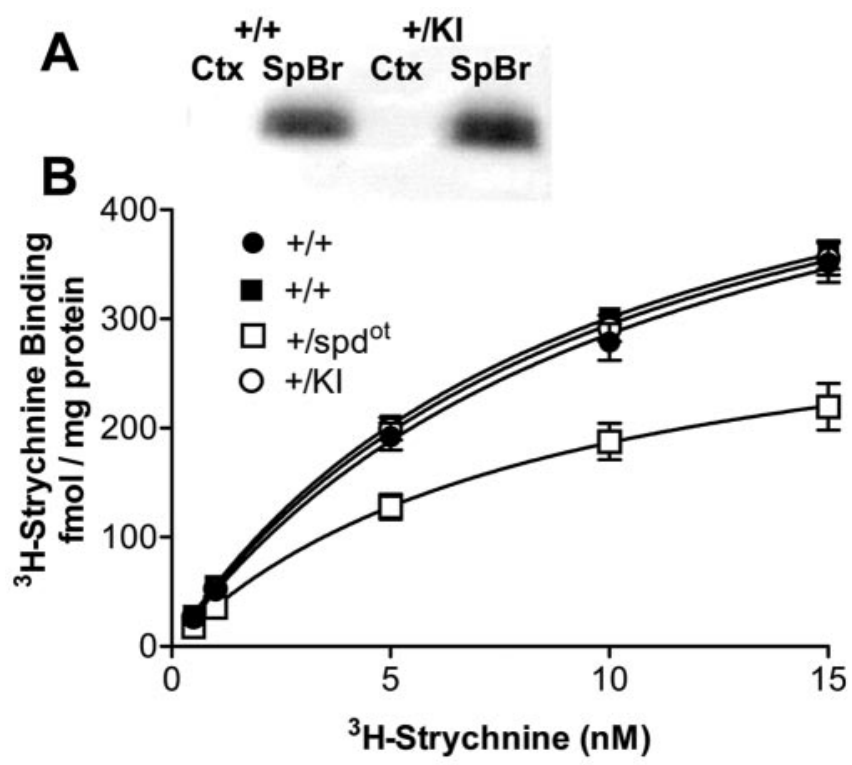

Figure 6. GlyR expression as measured by immunoblotting and ${ }^{3} \mathrm{H}$-strychnine binding. $A$, Immunoblotting was used to determine GlyR $\alpha$-subunit protein levels in wild-type $(+/+)$ and knock-in (+/KI) mice. Results from a typical immunoblot are shown. GlyR levels in the spinal cord and brainstem ( $\mathrm{SpBr}$ ) were indistinguishable between heterozygous knock-in and wildtype tissue ( $n=3$ per group). In addition, using this method, SpBr tissue taken from homozygous knock-in mice at postnatal day 18 displayed indistinguishable GlyR levels compared with wild-type controls ( $n=3$ per group). GlyR was not detected in the cortex (Ctx) of knock-in or wild-type mice. $B,{ }^{3} \mathrm{H}$-strychnine binding was measured in the combined spinal cord and brainstem of heterozygous spd $d^{\text {ot }}\left(+/\right.$ spd $^{\text {ot }}$ ) and heterozygous knock-in $(+/ K I)$ mice compared with corresponding wild-types $\left(+/+\right.$, filled squares) and $\left(+/+\right.$, filled circles), respectively. $B_{\max }$ values were $599 \pm 27,588 \pm 19,588 \pm 24$, and $347 \pm 38 ; K_{d}$ values were $11.6 \pm 1.5,10.2 \pm$ $0.8,9 \pm 0.5$, and $8.5 \pm 0.6$ for $+/+$ (filled circles),$+/ K I$ (open circles),$+/+$ (filled squares), and $+/ \mathrm{spd}^{\text {ot }}$ (open squares) mice, respectively ( $n=6-8$ per point per group). $+/+$ (filled circles), $+/+$ (filled squares), and $+/ K B_{\max }$ values were statistically indistinguishable. ${ }^{3} \mathrm{H}$ strychnine $B_{\max }$ values were reduced in $+/ \mathrm{spd}^{\text {ot }}$ mice ( $p<0.001$ using two-tailed $t$ test, $n=$ $6-8$ per point per group).

\section{Discussion}

The S267Q $\alpha_{1}$ GlyR knock-in mouse model demonstrates that heterozygous mice with a point mutation altering GlyR function exhibit a phenotype similar to forms of dominant hyperekplexia. This phenotype is more dramatic than that seen in heterozygous mice for the recessive null mutation $\left(s p d^{o t}\right)$, which are by comparison behaviorally asymptomatic. Unlike mutations that cause hyperekplexia by decreasing the glycine affinity of GlyR (Laube et al., 2002), the GlyR $\alpha_{1}$ S267Q mutation appears instead to decrease the efficacy of glycine. As noted previously (Findlay et al., 2002), no differences were observed in the glycine concentration-response relationships for wild-type and S267Q homomeric GlyR $\alpha_{1}$ receptors expressed in Xenopus laevis oocytes, and minimal changes in glycine sensitivity were observed in heteromeric $\alpha_{1} \beta$ and $\alpha_{1}$ (S267Q) $\beta$ GlyR, when results were expressed as the percentage of the maximal response. However, when the results are expressed in absolute currents, large differences emerged. In agreement with these data, maximal glycine-stimulated, strychnine-sensitive ${ }^{36} \mathrm{Cl}^{-}$uptake into synaptoneurosomes of the spinal cord and brainstem were reduced $\sim 50 \%$ in heterozygous knock-in mice.

Oscillator $\left(s p d^{o t}\right)$ mice have a 7 bp microdeletion in the gene for the GlyR $\alpha_{1}$-subunit that results in the complete lack of GlyR $\alpha_{1}$ polypeptide in homozygous ( $\mathrm{spd}^{\mathrm{ot}} / \mathrm{spd}^{\mathrm{ot}}$ ) mice; heterozygous mice had an $\sim 50 \%$ decrease in the GlyR $\alpha_{1}$-subunit and an $\sim 30 \%$ reduction in total GlyR levels (Kling et al., 1997). These 

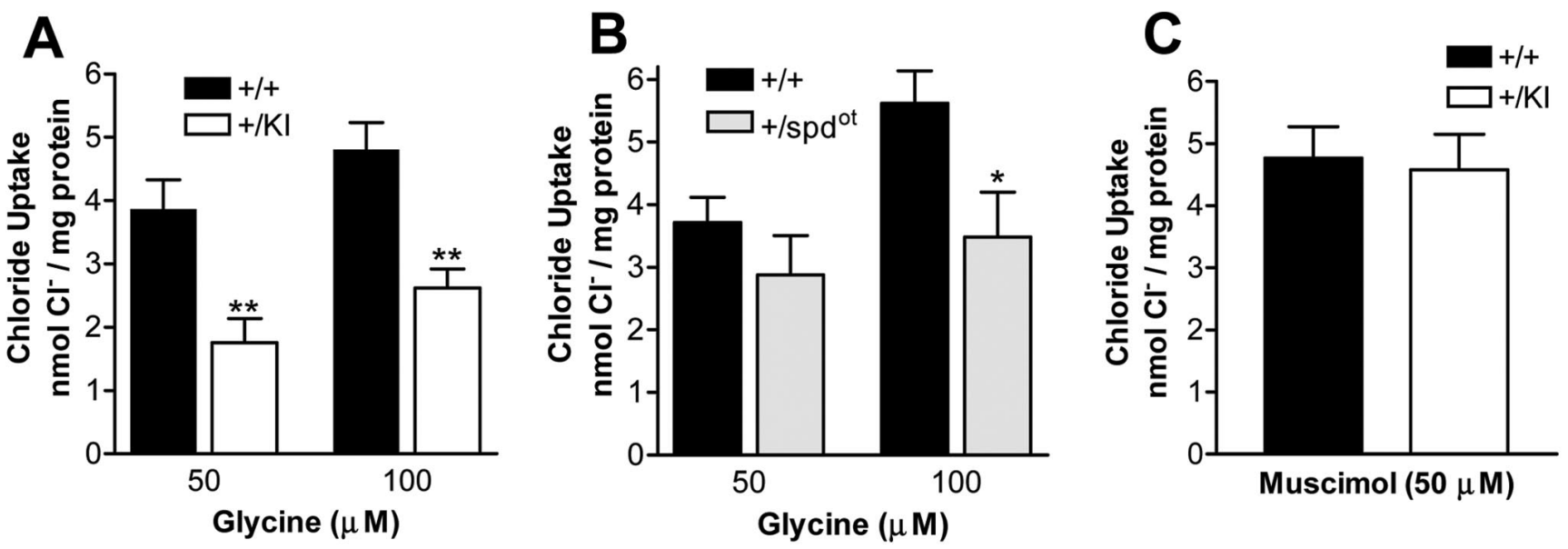

Figure 7. Glycine-stimulated strychnine-sensitive chloride uptake in synaptoneurosomes of spinal cord + brainstem. $A$, Maximal glycine responses were decreased in heterozygous knock-in mice $(+/ \mathrm{KI})(p<0.0001$ for genotype interaction using two-way ANOVA; $p<0.01$ using Bonferroni post tests for 50 and $100 \mu \mathrm{m}$ glycine; $n=9-10$ per group). $B$, Maximal glycine responses were also decreased in heterozygous spd $d^{\text {ot }}\left(+/\right.$ spd $^{\text {ot }}$ ) mice ( $p<0.05$ for genotype interaction using two-way ANOVA; $p<0.05$ using Bonferroni post tests for $100 \mu m$ glycine; $n=9$ per group). $C$, No changes in maximal GABA responses of heterozygous knock-in mice $(+/ \mathrm{KI})(n=6)$. Corresponding wild-type mice are labeled $(+/+)$.

Table 1. Glycine-stimulated ${ }^{36} \mathrm{Cl}^{-}$flux and ${ }^{3} \mathrm{H}$-strychnine $B_{\max }$ values

\begin{tabular}{lllc}
\hline & Flux $^{a}$ & $B_{\max }{ }^{b}$ & Flux $/ B_{\max }{ }^{c}$ \\
\hline WT-GlyKl & $4.8 \pm 0.4$ & $599 \pm 27$ & 8013 \\
GlyKl & $2.6 \pm 0.3^{d}$ & $588 \pm 19$ & 4421 \\
WT-Spd $^{\text {ot }}$ & $5.6 \pm 0.5$ & $588 \pm 24$ & 9864 \\
Spd $^{\text {ot }}$ & $3.5 \pm 0.7^{e}$ & $346 \pm 38^{d}$ & 10072 \\
\hline
\end{tabular}

${ }^{a}$ Flux is expressed in $\mathrm{nmol} \mathrm{Cl}^{-} / \mathrm{mg}$ of protein.

${ }^{b} B_{\text {max }}$ is expressed in $\mathrm{fmol}^{3} \mathrm{H}$-strychnine/mg of protein.

${ }^{c} \mathrm{Flux} / B_{\max }$ is expressed in $\mathrm{mol} \mathrm{Cl}^{-} / \mathrm{mol}^{3} \mathrm{H}$-strychnine.

${ }^{d} p<0.01$ compared with corresponding wild-type.

${ }^{e} p<0.05$ compared with corresponding wild-type.

results suggest that some compensation by GlyR subunit substitution may occur in heterozygous $s p d^{o t}$ mice. Consistent with these results, we observed an $\sim 40 \%$ reduction in GlyR levels using ${ }^{3} \mathrm{H}$-strychnine binding and chloride uptake. In contrast, GlyR levels were unaltered in heterozygous knock-in mice. The lack of ectopic GlyR expression in the cortex and identical GlyR levels in the spinal cord and brainstem demonstrate a substantial advantage of expression of the mutant GlyR $\alpha_{1}$ S267Q via the endogenous GlyR $\alpha_{1}$ promoter over transgenic expression of mutant GlyR (Becker et al., 2002; Findlay et al., 2002).

Unlike wild-type and heterozygous $s p d^{o t}$ mice, knock-in mice exhibited a hindfeet clenching or limb clenching phenotype when lifted by the tail. This phenotype is similar to that observed in homozygous spastic (spa) (Kingsmore et al., 1994; Mulhardt et al., 1994) or spasmodic (spd) mice (Ryan et al., 1994; Saul et al., 1994), which have mutations in GlyR $\alpha_{1}$ - and $\beta$-subunits, respectively. This may be a phenotype common to mutations leading to GlyR hypofunction. Unlike the spa and spd phenotypes, which are most pronounced during postnatal week 2-3 but progressively lessen with age (Kingsmore et al., 1994; Mulhardt et al., 1994; Ryan et al., 1994; Saul et al., 1994), the limb clenching phenotype is observed in adult GlyR $\alpha_{1}$ S267Q knock-in mice, suggesting that the S267Q mutation may produce a larger disruption of GlyR function or reduce the possibility of compensation compared with spa or $s p d$ mutations. Homozygous $s p d^{o t}$ mice also have a similar phenotype before death (Buckwalter et al., 1994). However, unlike these other mutants, heterozygous knock-in mice did not display episodes of myoclonus, and the righting abilities of these mice were not impaired.
The acoustic startle response is very sensitive to changes in GlyR function. Disruption of GlyR function by hyperekplexia mutations or by sublethal concentrations of strychnine will enhance startle responses. Previously, a modest increase in the startle responses for heterozygous $s p d^{o t}$ mice was observed (Kling et al., 1997). In the current study, no alteration in acoustic startle responses was observed in heterozygous $s p d^{o t}$ mice. It is possible that differences in experimental procedure can account for these differences or that subsequent generations of $s p d^{o t}$ mice have become more resistant to this phenotype. However, S267Q $\alpha_{1}$ GlyR knock-in mice display a tremendous increase in acoustic startle responses. Although different genetic backgrounds in mice can produce different behavioral responses (Crawley, 2000), the wild-type controls for $s p d^{o t}$ mice (C57BL/6J) and wild-type controls for knock-in mice $(\mathrm{C} 57 \mathrm{BL} / 6 \mathrm{~J} \times 129 / \mathrm{SvJ})$ have similar startle responses. This phenotype of the knock-in mice demonstrates that a point mutation altering receptor function can produce a larger impact on behavior than a corresponding null mutation for the same gene. Considering that the transgenic expression of a $\beta$-subunit that provided $\sim 50 \%$ of the wild-type ${ }^{3} \mathrm{H}$-strychnine binding was sufficient to rescue the phenotype of homozygous spastic (spa) mice (Hartenstein et al., 1996), it is likely that the mutant GlyR $\alpha_{1}$ S267Q subunit coassembles with other wild-type subunits to affect function adversely to a degree greater than that produced by a loss of half of the receptors. This idea is consistent with the decrease in chloride flux per receptor in $\alpha_{1}$ S267Q knock-in mice (Table 1), as well as the observation that $\alpha_{1}$ S267Q mutation decreases currents in heteromeric $\alpha_{1} \beta$ receptors (Fig. 2 ). Thus, the formation of mixed wild-type/mutant channel complexes may result in the dominant negative effect observed in S267Q knock-in mice. The S267Q $\alpha_{1}$ knock-in mutation may also decrease the potential for compensation that is seen in heterozygous $s p d^{o t}$ mice, perhaps because there is no shortage of $\alpha_{1}$-subunits seen in the knock-in animals; i.e., perhaps receptor number rather than receptor function per se determines whether compensation occurs.

In contrast to previous work showing that transgenic expression of a wild-type GlyR $\alpha_{1}$-subunit produced a progressive limb incoordination (Becker et al., 2002), the performance of heterozygous knock-in mice using the rotarod test was indistin- 


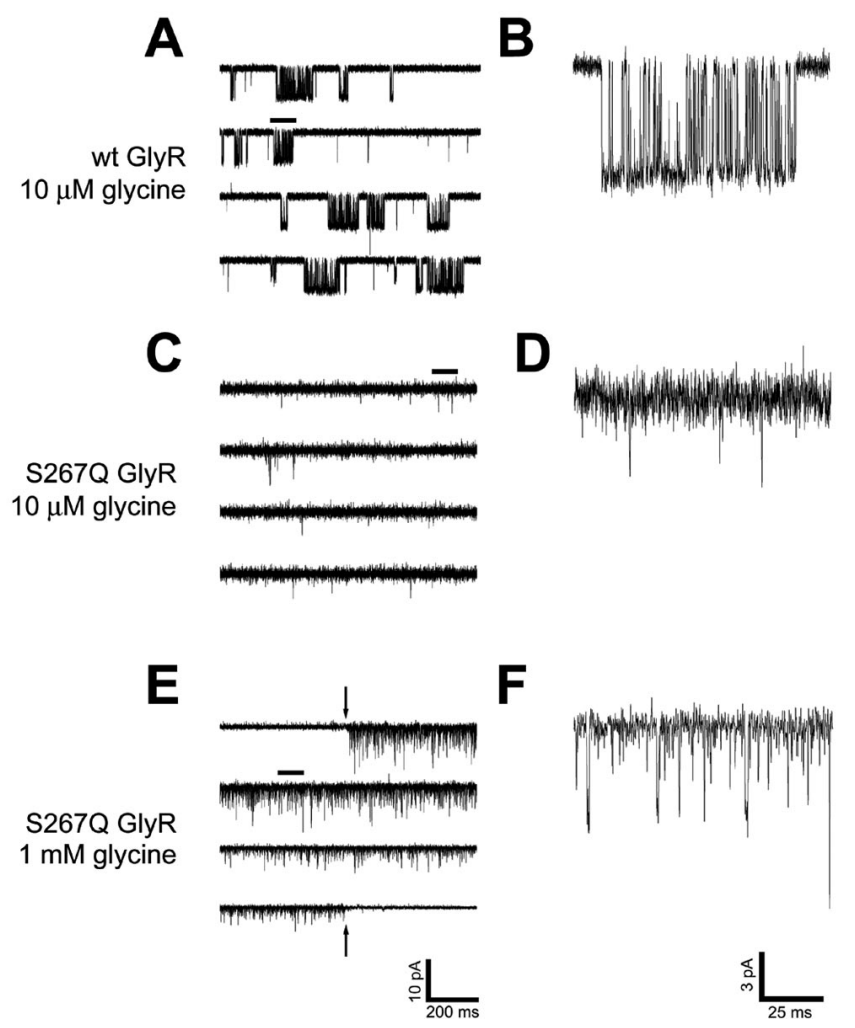

Figure 8. Single-channel tracings of glycine-activated currents from wild-type $(A, B)$ and S267Q ( $(-F) \alpha_{1}$ glycine receptors. Outside-out patches pulled from transiently transfected HEK 293 cells were voltage clamped at $-60 \mathrm{mV}$ and perfused with $10 \mu \mathrm{m}(A-D)$ or $1 \mathrm{~mm}(E, F)$ glycine. A portion of each of the tracings in the left-hand column (marked with a line above it) is expanded in the right-hand column to provide a detailed view of individual channel opening events. In $E$, the first $1.5 \mathrm{sec}$ and the final $1.5 \mathrm{sec}$ of a $60 \mathrm{sec}$ glycine application are shown with the preceding and following $0.5 \mathrm{sec}$ of baseline (included to indicate the quality of the patch). The downward- and upward-pointing arrows indicate the onset and offset, respectively, of the glycine application. Perfusion artifacts were subtracted. Whereas wild-type receptors exhibited bursts of openings to stable amplitude levels, S267Q receptors tended to open very briefly and exhibited little or no burst structure. Each panel is from a single patch but is representative of multiple $(n=5)$ patches tested.

guishable from the wild-type. Thus, although knock-in mice display profound increases in acoustic startle responses, this phenotype does not appear to extend to a more general ability of coordination. Although it has been postulated that GlyR function may be important for pain perception (Keller et al., 2001), no differences in pain perception of the knock-in mice were observed using the hot-plate latency test. However, it is possible that differences could still emerge using a different behavioral test.

$\mathrm{GABA}_{\mathrm{A}}$ receptor function was measured in the knock-in mice because previous data suggested that alterations in GlyR can affect $\mathrm{GABA}_{\mathrm{A}}$ receptor function. $\mathrm{GABA}_{\mathrm{A}}$ receptor protein expression levels are increased in spa mice (White and Heller, 1982; Biscoe et al., 1984). In addition, $\mathrm{GABA}_{\mathrm{A}}$ receptor function was decreased, although protein expression was unaltered, because of the transgenic expression of a mutant GlyR (Becker et al., 2002). In contrast, no alteration in $\mathrm{GABA}_{\mathrm{A}}$ receptor function was observed as a result of the S267Q $\alpha_{1}$ knock-in mutation, measured by muscimol-stimulated ${ }^{36} \mathrm{Cl}^{-}$uptake in spinal cord and brainstem synaptoneurosomes.

Our findings raise the question of how a point mutation in TM2 can produce such marked physiological changes in receptor function. Previous in vitro studies demonstrated that point mu- tations in the extracellular region linking TM2 and TM3 of GlyR are critical for coupling glycine binding to channel opening ( $\mathrm{Ra}$ jendra et al., 1995; Lynch et al., 1997; Lewis et al., 1998). Near the extracellular edge of TM2, the GlyR $\alpha_{1}$ Q266H mutation can cause dominant hyperekplexia (Milani et al., 1996). The Q266H mutation reduces the open channel time (similar to S267Q) and decreases the potency of glycine and taurine (unlike S267Q) without altering single-channel conductance, the ion/cation selectivity ratio, strychnine binding, or the effects of several modulators $\left(\mathrm{Zn}^{2+}, \mathrm{pH}\right.$, and DEPC) (Moorhouse et al., 1999). It has been postulated that Q266H stabilizes the closed state of the receptor (Tang et al., 2002), and S267Q may function via a similar mechanism. The S267 site is located near this region and is of interest because it is important for the effects of alcohols and volatile anesthetics and seems to be part of an alcohol and anesthetic binding site (Mihic et al., 1997; Mascia et al., 2000b), and the S267Q mutation can affect the allosteric modulation of GlyR function by alcohol and anesthetics (Mascia et al., 2000a; Findlay et al., 2002). Ethanol is changed from a positive to a negative allosteric modulator by the S267Q mutation (Findlay et al., 2002), strongly suggesting that S267 is involved with channel gating. Mutations at the homologous amino acid in $\mathrm{GABA}_{\mathrm{A}}$ receptors can also alter channel gating by drastically reducing allosteric modulation, increasing GABA sensitivity, and producing spontaneous channel openings (Findlay et al., 2001; Nishikawa et al., 2002). The results of GlyR TM2 NMR structure analyses suggest that a mere $10^{\circ}$ of rotation of the TM2 regions could be sufficient to induce channel gating; this work also demonstrates that single amino acid mutations at S267 are likely to alter channel gating (Tang et al., 2002), although the S267 residue appears to face away from the channel (Trudell and Bertaccini, 2002). Because strychnine and glycine share overlapping binding sites, the similar affinity of strychnine binding to wild-type and S267Q mutant receptors provide evidence that the mutation has not altered the binding site. Furthermore, the S267Q mutation reduced maximal glycine responses in knock-in mouse synaptoneurosomes, as measured using chloride uptake. Finally, briefer channel openings in cell-detached patches containing GlyR $\alpha_{1}$ S267Q suggest changes in channel gating, although changes in conductance or in vivo receptor trafficking cannot be ruled out. These changes are consistent with the idea that S267 is involved with allosteric transitions required for channel gating and may also explain the lethality of this mutation in vivo.

We propose that construction of knock-in mice bearing defective receptors may provide an additional avenue to assess the roles of a particular receptor, complementing studies involving the deletion (knock-out) of genes. Deletion of a protein often allows for the substitution of related proteins, especially for receptors such as the $\mathrm{GABA}_{\mathrm{A}}$ receptor, in which there are many related subunits (Kralic et al., 2002; Peng et al., 2002; Ramadan et al., 2003). In the case of the glycine $\alpha_{1}$-subunit, it is likely that the marked differences seen in heterozygous mice are caused by sufficient substitution or sufficient function of the normal allele in $s p d^{o t}$ mice, but little or no substitution and more impaired GlyR function in the S267Q mouse. In homozygous mice, sufficient substitution is not possible, and both mutations are lethal. In conclusion, these studies demonstrate that a point mutation in the $\alpha_{1}$ GlyR can produce a more dramatic phenotype than the corresponding null mutation and demonstrate that the S267 residue plays a critical role in allosteric transitions required for channel function in vivo. 


\section{References}

Beato M, Groot-Kormelink PJ, Colquhoun D, Sivilotti LG (2002) Openings of the rat recombinant alpha 1 homomeric glycine receptor as a function of the number of agonist molecules bound. J Gen Physiol 119:443-466.

Becker CM, Schmieden V, Tarroni P, Strasser U, Betz H (1992) Isoformselective deficit of glycine receptors in the mouse mutant spastic. Neuron 8:283-289.

Becker L, von Wegerer J, Schenkel J, Zeilhofer HU, Swandulla D, Weiher H (2002) Disease-specific human glycine receptor alphal subunit causes hyperekplexia phenotype and impaired glycine- and GABA(A)-receptor transmission in transgenic mice. J Neurosci 22:2505-2512.

Beckstead MJ, Weiner JL, Eger EI, 2nd, Gong DH, Mihic SJ (2000) Glycine and gamma-aminobutyric acid(A) receptor function is enhanced by inhaled drugs of abuse. Mol Pharmacol 57:1199-1205.

Biscoe TJ, Fry JP, Rickets C (1984) Changes in benzodiazepine receptor binding as seen autoradiographically in the central nervous system of the spastic mouse. J Physiol (Lond) 352:509-516.

Blednov YA, Bleck V, Harris RA (1996) Measurement of glycine receptor function by radioactive chloride uptake. J Neurosci Methods 68:253-257.

Buckwalter MS, Cook SA, Davisson MT, White WF, Camper SA (1994) A frameshift mutation in the mouse alpha 1 glycine receptor gene (Glra1) results in progressive neurological symptoms and juvenile death. Hum Mol Genet 3:2025-2030.

Bullock AE, Slobe BS, Vazquez V, Collins AC (1997) Inbred mouse strains differ in the regulation of startle and prepulse inhibition of the startle response. Behav Neurosci 111:1353-1360.

Crawley JN (2000) What's wrong with my mouse? Behavioral phenotyping of transgenic and knockout mice. New York: Wiley.

Crestani F, Low K, Keist R, Mandelli M, Mohler H, Rudolph U (2001) Molecular targets for the myorelaxant action of diazepam. Mol Pharmacol 59:442-445.

Findlay GS, Ueno S, Harrison NL, Harris RA (2001) Allosteric modulation in spontaneously active mutant gamma-aminobutyric acid $_{\mathrm{A}}$ receptors. Neurosci Lett 305:77-80.

Findlay GS, Wick MJ, Mascia MP, Wallace D, Miller GW, Harris RA, Blednov YA (2002) Transgenic expression of a mutant glycine receptor decreases alcohol sensitivity of mice. J Pharmacol Exp Ther 300:526-534.

Groot-Kormelink PJ, Beato M, Finotti C, Harvey RJ, Sivilotti LG (2002) Achieving optimal expression for single channel recording: a plasmid ratio approach to the expression of alpha 1 glycine receptors in HEK293 cells. J Neurosci Methods 113:207-214.

Hamill OP, Marty A, Neher E, Sakmann B, Sigworth FJ (1981) Improved patch-clamp techniques for high-resolution current recording from cells and cell-free membrane patches. Pflugers Arch 391:85-100.

Hartenstein B, Schenkel J, Kuhse J, Besenbeck B, Kling C, Becker CM, Betz H, Weiher H (1996) Low level expression of glycine receptor beta subunit transgene is sufficient for phenotype correction in spastic mice. EMBO J 15:1275-1282.

Homanics GE, Ferguson C, Quinlan JJ, Daggett J, Snyder K, Lagenaur C, Mi ZP, Wang XH, Grayson DR, Firestone LL (1997) Gene knockout of the alpha- 6 subunit of the gamma-aminobutyric acid type A receptor: lack of effect on responses to ethanol, pentobarbital, and general anesthetics. Mol Pharmacol 51:588-596.

Keller AF, Coull JA, Chery N, Poisbeau P, De Koninck Y (2001) Regionspecific developmental specialization of GABA-glycine cosynapses in laminas I-II of the rat spinal dorsal horn. J Neurosci 21:7871-7880.

Kingsmore SF, Giros B, Suh D, Bieniarz M, Caron MG, Seldin MF (1994) Glycine receptor beta-subunit gene mutation in spastic mouse associated with LINE-1 element insertion. Nat Genet 7:136-141.

Kirsch J, Betz H (1995) The postsynaptic localization of the glycine receptor-associated protein gephyrin is regulated by the cytoskeleton. J Neurosci 15:4148-4156.

Kling C, Koch M, Saul B, Becker CM (1997) The frameshift mutation oscillator (Glra1(spd-ot)) produces a complete loss of glycine receptor alpha ${ }_{1}$-polypeptide in mouse central nervous system. Neuroscience 78:411-417.

Kralic JE, Korpi ER, O’Buckley TK, Homanics GE, Morrow AL (2002) Molecular and pharmacological characterization of GABA(A) receptor alpha $_{1}$ subunit knockout mice. J Pharmacol Exp Ther 302:1037-1045.
Kuhse J, Betz H, Kirsch J (1995) The inhibitory glycine receptor: architecture, synaptic localization and molecular pathology of a postsynaptic ionchannel complex. Curr Opin Neurobiol 5:318-323.

Laube B, Maksay G, Schemm R, Betz H (2002) Modulation of glycine receptor function: a novel approach for therapeutic intervention at inhibitory synapses? Trends Pharmacol Sci 23:519-527.

Lewis TM, Sivilotti LG, Colquhoun D, Gardiner RM, Schoepfer R, Rees M (1998) Properties of human glycine receptors containing the hyperekplexia mutation alpha1(K276E), expressed in Xenopus oocytes. J Physiol 507(Pt 1):25-40.

Low K, Crestani F, Keist R, Benke D, Brunig I, Benson JA, Fritschy JM, Rulicke T, Bluethmann H, Mohler H, Rudolph U (2000) Molecular and neuronal substrate for the selective attenuation of anxiety. Science 290:131-134.

Lynch JW, Rajendra S, Pierce KD, Handford CA, Barry PH, Schofield PR (1997) Identification of intracellular and extracellular domains mediating signal transduction in the inhibitory glycine receptor chloride channel. EMBO J 16:110-120.

Malosio ML, Marqueze-Pouey B, Kuhse J, Betz H (1991) Widespread expression of glycine receptor subunit mRNAs in the adult and developing rat brain. EMBO J 10:2401-2409.

Mascia MP, Gong DH, Eger EI, 2nd, Harris RA (2000a) The anesthetic potency of propanol and butanol versus propanethiol and butanethiol in $\mathrm{alpha}_{1}$ wild type and $\mathrm{alpha}_{1}(\mathrm{~S} 267 \mathrm{Q})$ glycine receptors. Anesth Analg 91:1289-1293.

Mascia MP, Trudell JR, Harris RA (2000b) Specific binding sites for alcohols and anesthetics on ligand-gated ion channels. Proc Natl Acad Sci USA 97:9305-9310.

McKernan RM, Rosahl TW, Reynolds DS, Sur C, Wafford KA, Atack JR, Farrar S, Myers J, Cook G, Ferris P, Garrett L, Bristow L, Marshall G, Macaulay A, Brown N, Howell O, Moore KW, Carling RW, Street LJ, Castro JL, et al. (2000) Sedative but not anxiolytic properties of benzodiazepines are mediated by the $\operatorname{GABA}(\mathrm{A})$ receptor alpha ${ }_{1}$ subtype. Nat Neurosci 3:587-592.

Meyer G, Kirsch J, Betz H, Langosch D (1995) Identification of a gephyrin binding motif on the glycine receptor beta subunit. Neuron 15:563-572.

Meyers EN, Lewandoski M, Martin GR (1998) An Fgf8 mutant allelic series generated by Cre- and Flp-mediated recombination. Nat Genet $18: 136-141$.

Mihic SJ, Ye Q, Wick MJ, Koltchine VV, Krasowski MD, Finn SE, Mascia MP, Valenzuela CF, Hanson KK, Greenblatt EP, Harris RA, Harrison NL (1997) Sites of alcohol and volatile anaesthetic action on GABA(A) and glycine receptors. Nature 389:385-389.

Milani N, Dalpra L, del Prete A, Zanini R, Larizza L (1996) A novel mutation (Gln266-> His) in the alpha $a_{1}$ subunit of the inhibitory glycine-receptor gene $\left(\mathrm{GLRA}_{1}\right)$ in hereditary hyperekplexia. Am J Hum Genet $58: 420-422$.

Moorhouse AJ, Jacques P, Barry PH, Schofield PR (1999) The startle disease mutation Q266H, in the second transmembrane domain of the human glycine receptor, impairs channel gating. Mol Pharmacol 55:386-395.

Mulhardt C, Fischer M, Gass P, Simon-Chazottes D, Guenet JL, Kuhse J, Betz H, Becker CM (1994) The spastic mouse: aberrant splicing of glycine receptor beta subunit mRNA caused by intronic insertion of L1 element. Neuron 13:1003-1015.

Nishikawa K, Jenkins A, Paraskevakis I, Harrison NL (2002) Volatile anesthetic actions on the GABAA receptors: contrasting effects of alpha (S270) and beta $_{2}(\mathrm{~N} 265)$ point mutations. Neuropharmacology 42:337-345.

Peng Z, Hauer B, Mihalek RM, Homanics GE, Sieghart W, Olsen RW, Houser CR (2002) GABA(A) receptor changes in delta subunit-deficient mice: altered expression of alpha4 and gamma2 subunits in the forebrain. J Comp Neurol 446:179-197.

Rajendra S, Lynch JW, Pierce KD, French CR, Barry PH, Schofield PR (1995) Mutation of an arginine residue in the human glycine receptor transforms beta-alanine and taurine from agonists into competitive antagonists. Neuron 14:169-175.

Ramadan E, Fu Z, Losi G, Homanics GE, Neale JH, Vicini S (2003)

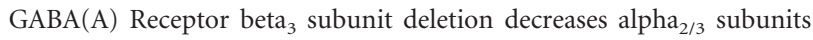
and IPSC duration. J Neurophysiol 89:128-134. 
Rodriguez CI, Buchholz F, Galloway J, Sequerra R, Kasper J, Ayala R, Stewart AF, Dymecki SM (2000) High-efficiency deleter mice show that FLPe is an alternative to Cre-loxP. Nat Genet 25:139-140.

Ryan SG, Buckwalter MS, Lynch JW, Handford CA, Segura L, Shiang R, Wasmuth JJ, Camper SA, Schofield P, O’Connell P (1994) A missense mutation in the gene encoding the alpha 1 subunit of the inhibitory glycine receptor in the spasmodic mouse. Nat Genet 7:131-135.

Saul B, Schmieden V, Kling C, Mulhardt C, Gass P, Kuhse J, Becker CM (1994) Point mutation of glycine receptor alpha 1 subunit in the spasmodic mouse affects agonist responses. FEBS Lett 350:71-76.

Shiang R, Ryan SG, Zhu YZ, Hahn AF, O’Connell P, Wasmuth JJ (1993) Mutations in the alpha 1 subunit of the inhibitory glycine receptor cause the dominant neurologic disorder, hyperekplexia. Nat Genet 5:351-358.

Tang P, Mandal PK, Xu Y (2002) NMR structures of the second transmembrane domain of the human glycine receptor alpha(1) subunit: model of pore architecture and channel gating. Biophys J 83:252-262.

Trudell JR, Bertaccini E (2002) Molecular modelling of specific and nonspecific anaesthetic interactions. Br J Anaesth 89:32-40.

White WF, Heller AH (1982) Glycine receptor alteration in the mutant mouse spastic. Nature 298:655-657.

Wick MJ, Bleck V, Whatley VJ, Brozowski SJ, Nixon K, Cardoso RA, Valenzuela CF (1999) Stable expression of human glycine alpha ${ }_{1}$ and alpha ${ }_{2}$ homomeric receptors in mouse L(tk-) cells. J Neurosci Methods 87:97-103. 